\title{
Trade Liberalization and the Lead Role of Human Capital and Job Attributes in Wage Determination: The Case of Pakistan's Labor Market
}

\section{Bushra Yasmin *}

\begin{abstract}
This study analyzes the role of human capital and job attributes, i.e., supply-side determinants, in determining wages in a period of trade liberalization. Using the Mincerian earning function and based on data from the Labor Force Surveys, we construct a model to estimate various wage determinants and compute the rates of return to different educational qualifications and relative occupational wage shares for the years 2005/06 and 1990/91. The estimated earning functions for 1990/91 and 2005/06 are compared to investigate whether individual characteristics-such as gender, job location, nature of job, educational qualifications, and different occupations-cause the wage gap to widen or contract under conditions of trade liberalization. The mean and quantile regression approach is used for estimation purposes. Our key findings postulate (i) an increasing gender pay gap, (ii) a higher wage premium to the highest educational qualification, and (iii) more or less stable relative wages for different occupations over time. In addition, wage dispersion across occupational groups appears more pronounced in 1990/91 than in 2005/06, implying a declining trend in the difference in wage distribution across occupations. Our findings suggest that trade liberalization cannot be presumed to pose a threat to the labor market in the wage context. However, exposing labor to an open market has not increased the productivity and skills of labor or helped reap the potential benefits of trade liberalization.
\end{abstract}

JEL Classification: F16, J31.

Keywords: Trade liberalization, wage determination, human capital, Pakistan.

\footnotetext{
* Department of Economics, Fatima Jinnah Women University, Rawalpindi, Pakistan.
} 


\section{Introduction}

Trade openness has been regarded as a key element of any development policy at the global level since the late 1970s. Openness, better explained as "trade liberalization" in this context, connotes a reduction in barriers to the movement of goods and services in international trade. Edwards (1993) describes a liberal trade regime as one in which all trade distortions, including import tariffs and export subsidies, are completely eliminated. The benefits of trade liberalization, if done collectively with other countries, multiply significantly, but the profitability of liberalization can only be confirmed by the proliferation of its positive effects on the economy. In this regard, the argument is generally in favor of trade liberalization in its role of leading the economy to a higher growth rate at the national and international level.

Trade liberalization is generally favored on the grounds of (i) facilitating economic growth-given its dynamic advantages of higher capacity utilization and more efficient investment-and (ii) promoting the performance of export growth and increasing productivity. As liberalization policies remove restrictions on trade between countries, producers have access to the inputs required to produce more efficiently, while new overseas markets are opened to exporters and opportunities are broadened for existing export industries. This liberalization is expected to reallocate resources according to comparative advantage while large-scale operations flourish, given greater economies of scale.

However, there are certain costs associated with trade liberalization, such as loss in tariff revenue, which accounts for 10 to $20 \%$ of government revenue in developing countries. A larger burden of domestic taxes-such as sales tax-to compensate for this loss and heavy reliance on borrowing to finance the fiscal deficit collectively raises the country's overall debt. This exacerbates the problem and has distortionary effects on the economy. Moreover, tariff reductions deprive a country's domestic industry of protection, leading to adverse effects on existing industries and the services sector. It is also commonly held that the gains from trade liberalization are not distributed uniformly among economies generally and within a country specifically.

Proponents of trade liberalization typically regard labor as one of its chief beneficiaries. According to standard trade theory, countries with an abundant labor supply reallocate resources toward labor-intensive goods, leading to an increase in demand for labor. Depending on the prevailing labor market conditions, the resulting increase in demand for labor 
translates into some combination of an increase in employment and wages. While the logic of this argument is fairly compelling and is generally supported by the experience of the early liberalized and newly industrialized economies of East Asia (Hong Kong, Korea, Singapore, and Taiwan), more recent episodes of trade liberalization appear not to have been associated with large improvements in prospects for the typical worker (Robbins 1996, Wood 1997).

Pakistan has a comparative advantage in three key areas: (i) agriculture, (ii) textiles, and (iii) services; an overwhelming proportion of workers in Pakistan are engaged in these sectors. In the standard trade theory context, we would expect openness to cause a significant boost in employment, production, and growth of the economy. On the labor demand side, trade liberalization might affect own-wage elasticities through at least three channels: (i) substitutability of inputs, (ii) product demand elasticities, and (iii) the degree of collusion in the industry. The importance of the labor-demand elasticity element with respect to trade was first emphasized by Rodrik (1997), who argued that strengthening competition in the goods market would increase the sensitivity of factor demand to shocks, and the increased competitiveness of output markets and greater access to foreign inputs would lead to a more elastic demand for labor. This would, in turn, bring about greater volatility in the labor market since bad shocks to output translate into a greater impact on wages and employment.

The modest but growing body of literature linking trade with labor provides weak evidence of employment effects. Labor reallocation is assumed to be limited in developing countries in the wake of trade liberalization due to labor market rigidities, and trade reforms can affect the labor market through wages rather than employment channels as proposed by Goldberg and Pavcnik (2004). However, no empirical evidence for Pakistan- using micro-level data and controlling for observable workers' characteristics-is yet available to verify this common belief. The literature linking trade with wage effects concentrates mostly on developed countries while the evidence for developing countries is limited and apt to yield mixed results.

Using micro-data from the Labor Force Surveys (LFS) for two years, $2005 / 06$ and 1990/91, this study is an attempt to explore trade-labor links through the wage effects of trade liberalization, while controlling for observable workers' characteristics. ${ }^{1}$ An augmented Mincerian earnings

\footnotetext{
${ }^{1}$ The data on wages was available from the Labor Force Survey of year 1990-91 onward hence this year as initial period of trade liberalization was selected to compare the results with the results of year 2005-06.
} 
function is estimated for the years 1990/91 and 2005/06, and the estimated results are compared to verify whether any change in wage determination took place over this period from different perspectives, including gender gap, educational qualifications, job attributes, type of residence, and occupational choice. This, in turn, helps us measure wage inequality (widening or contracting wage gaps as a consequence of trade liberalization) among workers. The rate of return to different educational qualifications and relative wage shares among different occupations are also computed to allow deeper insight into trade-related changes in the wage premium. The econometric methodology applied is mean and quantile regression. The latter serves to analyze wage structure at different points of the conditional wage distribution: a recent approach not analyzed by any study in this framework.

The remaining study is organized as follows. Section II provides a brief literature review and historical overview of Pakistan's trade liberalization and labor market. Sections III and IV outline the model's specifications followed by econometric methodology. Section V details the data used. The last sections elaborate on the empirical results achieved, and conclude with some policy suggestions.

\section{Historical Background}

\section{II.1 Literature on Wages and Trade}

The main studies that examine the wage effects of trade liberalization based on micro-data while controlling for observable workers' characteristics and using wage regression models include: Gaston and Trefler (1994), Hanson and Harrison (1999), Beyer, Rojas, and Vergara (1999), Feliciano (2001), Goldberg and Pavcnik (2004), Hasan and Chen (2004), and Dutta (2007). Wage premiums are related to earning function estimates that include controls for various observable workers' characteristics such as sex, age, experience, location, and education attained. A two-step procedure is used to find such a link. The wage premium is, in turn, related to trade policy, trade flows, and industry characteristics. Gaston and Trefler (1994) find that tariffs had a negative effect on relative wages in the US, while Feliciano (2001), Hasan and Chen (2003), and Pavcnik, et al (2004) find that, once industry fixed effects are controlled for, tariffs had no statistically significant effects in Mexico, the Philippines, and Brazil, respectively. Jean and Nicoletti (2002) find that tariffs had a significant positive impact on relative wages in the manufacturing industries of 12 OECD countries, including the US. 
For Pakistan, there is a dearth of studies specifically devoted to finding out the changing role of the factors affecting wage determination and its linkage with the phases of trade liberalization. But a number of studies dealing only with wage determination using older years data sources including Labor Force Surveys (LFS) and Pakistan Integrated Household Survey (PIHS) are of Hyder and Reilly (2005), Shabbir (1994), Khan and Irfan (1985) and Haque (1984). These studies adopted different specifications with the background of Mincerian earnings function and found various individual workers' characteristics specifically gender, experience and education as major determinants of wages in Pakistan's labor market.

In general, the East Asian experience shows a reduction in wage inequality after openness strongly oriented toward exports. This is consistent with standard trade theory, which predicts that trade liberalization should benefit the locally abundant factor [Wood (1994) and (1999); Krueger (1983) and (1990)]. However, the generality of this outcome has been challenged by many studies. Robbins and Gindling (1999) investigate the changes in relative wages and in the supply and demand for skilled labor in Costa Rica before and after trade liberalization. They find that the skill premium rose after liberalization as a result of changes in the structure of labor demand. Beyer, et al (1999) use a time series approach and find that a long-term correlation exists between openness and wage inequality in Chile. Hanson and Harrison (1999) examine wage and employment changes in Mexico and find little variation in employment levels but a significant increase in skilled workers' relative wages. Likewise, Feliciano (2001) finds that the increase in returns to education in Mexico contributed to the rise of relative wages of skilled workers. Similarly, Green, et al (2001) find an increase in the returns to college education following trade liberalization and attribute this to rising relative demand for college-educated workers. Hence, the evidence on wage inequality linked to trade liberalization suggests an overall positive relationship between trade and wage inequality.

\section{II.2 Trade Policy and Labor Market Implications: Pakistan's Perspective}

This section provides a brief review of trade liberalization and labor policies adopted by different Pakistani governments over time.

\section{Evolution of Trade Policy}

A weak industrial base, dominant agricultural sector, lack of wellorganized infrastructure, and macroeconomic and political instability characterize the early years of Pakistan's economy. During this time, Pakistan adopted a restrictive trade regime by imposing high tariff and non- 
tariff barriers as a means to protect/promote industrialization. From 1953 to 1964, virtually all imports into Pakistan were regulated by some form of quantitative control.

The trade policy adopted by Pakistan after 1952 had three major components: (i) overvaluation of the Pakistan rupee relative to other countries, (ii) use of quantitative controls on imports to regulate the level and composition of imported goods, and (iii) a highly differentiated structure of tariffs on imports and export taxes on two principal agricultural exports, jute and cotton. This led to a particular type of import-substituting industrialization. There was no real export promotion policy until at least 1956, when an export promotion scheme, which covered 67 primary commodities and 58 manufacturing goods, was introduced, entitling exporters to import licenses for certain specific items to the extent of $25 \%$ and $40 \%$ on various categories of manufacturing goods and $15 \%$ on the export of raw materials (Ahmed 1984). The new trade policy in 1959 shifted toward indirect controls on imports and on the domestic price of other goods. During the 1960s, there was direct emphasis on the promotion of manufactured exports through the introduction of the Export Bonus Scheme 1959 (EBS) - a multiple exchange rate system. In addition, an importliberalizing program was started in 1959 .

In 1972, the Government took steps to abolish the import licensing system, multiple exchange rate system, and EBS; the import of luxury items was also banned. The most dramatic step taken was the devaluation of the rupee by $56 \%$ from PRs 4.74 to USD1 to Rs11; after the US dollar was devalued in 1973, the rupee settled at a new exchange value of Rs9.90 to USD1, a rate that remained fixed for about 8 years. After the devaluation of the rupee, there was a considerable change in import policy. Exports grew by $38.4 \%$ and $24.7 \%$ in $1973 / 3$ and $1973 / 74$, respectively, as a result of devaluation. Later, the Government adopted a series of steps to liberalize the trade regime. The number of banned goods was reduced and most nontariff barriers, which had been imposed after the oil shock and foreign exchange stringency of the 1970s, were removed. Between 1977 and 1983, the number of items on the free list was increased and the procedure for importing commodities was streamlined. The Government negotiated a substantial move toward trade liberalization with the International Monetary Fund (IMF) and World Bank in the early 1980s.

Reductions in quantitative barriers continued during the 1980s and 1990s. Each year, at the time the budget and trade policy were finalized, measures aimed at trade liberalization were announced although tariff reforms were slow to be implemented. The fear of loss of revenue because 
of tariff reforms by the Government was an important consideration in the implementation of these reforms. However, the pace of trade reforms had increased by 1988/89 (HDC 2001).

Although the trade regime in Pakistan experienced its most restrictive stage in the 1980s, the scope of nontariff barriers was significantly reduced and a negative import system adopted as part of the import regime in the early 1980s. Later, duties were eliminated on 100 commodity categories (mainly raw material and capital goods). Despite these measures, Pakistan's nominal tariff rates for manufacturing industries in 1986 were still among the highest in the world (Sayeed 1995). The most significant change was the formulation of a new trade policy in 1987. The salient features of this trade policy were as follows: (i) the number of tariff slabs was cut down to 10 from 17, (ii) a uniform sales tax of $12.5 \%$ replaced previous rates that varied across commodities, and (iii) maximum tariff rates were reduced to $125 \%$ from $225 \%$. Economy-wide, the average tariff rate declined by 8 percentage points in 1987/88. The most important policy that affected exports was the delinking of the Pakistan rupee from the US dollar and the introduction of a flexible exchange rate system.

Under its first major structural adjustment program in 1988, the Government committed to making extensive changes in its trade regime. By 1993, a number of steps based on the structural adjustment program had been taken. In March 1993, import licenses were abolished for all goods except those on the negative and restricted list. The maximum tariff was reduced from $225 \%$ in 1988 to $70 \%$ in $1994 / 95$. The country moved further toward trade liberalization by gradually decreasing import duties on consumer as well as capital goods. The maximum rate of tariff in 2000/01 was $30 \%$, with the exception of automobiles and alcoholic beverages, which attracted higher rates of duty. Duty rates for the period 2000-2003 show that the decline in the duty rate on capital goods was higher than on consumer goods: duty rates on consumer goods declined by $8 \%$ while duty rates on capital goods declined by $11 \%$. This was stated in the announcement of the trade policy for 2003/04: as part of the new multilateral trading system envisaged in the World Trade Organization (WTO) regime starting in 1995 and maturing in 2005, all quantitative restrictions on the export and import of textiles and clothing would be eliminated from 1 January 2005 . The imports increased by $17.8 \%$, because of higher imports of edible oils, increases in POL imports; an increase of $75 \%$ in machinery group imports (mainly of textile machinery, electrical machinery and agricultural machinery). 
The tax and tariff policies in the 2004/05 trade policy have, in particular, been used to serve the national objective of bringing about an industrial turnaround to achieve macroeconomic goals. According to the trade policy for 2005/06, a rapid export growth strategy was introduced to facilitate a quantum jump in the level of exports, based on the following five pillars: (i) resort to trade diplomacy to increase market access, (ii) regional diversification of exports market, (iii) strengthening of trade promotion infrastructure, (iv) skill development, and (v) early provision of modern infrastructure.

\section{Labor Policies in Pakistan}

Since independence, five labor market policies have been announced by the Government in 1955, 1959, 1969, 1972, and 2002, laying down parameters for the growth of trade unionism, protection of workers' rights, settlement of industrial disputes, and redress of workers' grievances. Pakistan's Labor Policy 2002 is based on the International Labor Organization (ILO)'s core standards and provides an essential, but necessarily broad, framework for the future development of the country's labor protection system, with particular reference to industrial relations and some aspects of labor protection.

Historically, the 1960s and 1970s were a turbulent period in the history of industrial relations in Pakistan. Militant trade unions and equally intransigent management were locked in endless disputes and conflicts over pay and working conditions. Strikes, go-slows, lockouts, and litigation were the most distinctive features of employer-employee relations. The concept of employers and employees working together in close cooperation to ensure productivity, profitability and growth of businesses, and security of employment was largely nonexistent. There was no realization that job security and appropriate wages were critically important for profitability and the continued competitiveness of businesses. As a consequence, both the entrepreneur and labor suffered greatly. Perhaps labor suffered most on account of increasing unemployment and declining real wages as both public and private sector businesses increasingly resorted to cutbacks, relocation, closures, contract employment, and outsourcing in an effort to maintain profits and counter pressure from trade unions. The progressive globalization of the economy is bringing forth even more formidable challenges and pressures. Today, however, a different scenario is emerging. Sobered by the negative experiences of adversarial industrial relations over past decades, trade unions are increasingly discarding militancy while employers are recognizing the need and benefits of co-opting 1abor as partners-in-productivity. Both employers and trade unions are progressively 
becoming involved in bilateral dialogue with the growing realization that the common interest of both employers and employees is best served by securing business profitability and growth. A new labor policy was formulated (as the first after 1972) in 2002.

The labor policy 2002 makes specific reference to a range of industrial relations issues, including the strengthening of bilateralism and social dialogue, the promotion of responsible trade unionism, the consolidation and rationalization of labor laws, and respect for international labor standards. The labor protection policy 2006 includes a number of issues not addressed in the labor policy, such as minimum wages and related matters, unemployment insurance, and labor market flexibility. The labor inspection policy 2006 provides a new direction for Pakistan's labor inspection systems to enable them to respond to a wide range of labor issues.

In 2007, the population of Pakistan was approximately 165 million. According to the Labor Force Survey (LFS) 2005/06, 50.05 million people are currently active as part of the "labor force." This comprises all persons 10 years of age or above who fulfill the requirements for inclusion among the employed or unemployed according to the LFS. The employed comprise all persons ten years of age or above who have worked at least 1 hour during the reference period and were either "paid employed" or "self employed." The unemployed are defined as all persons ten years of age or above who, during the reference period, were "without work," "currently available for work," or "seeking work." In 2005/06, the number of employed was 46.94 million and the number of unemployed 3.11 million. Of the total labor force, 39.97 million are male and 10.08 million are female. In terms of sectoral distribution, $43.4 \%$ are engaged in agriculture and allied industries, $20.7 \%$ in manufacturing, and $35.9 \%$ in the services sector. Employment by major industry divisions apportions the largest slice $(35 \%)$ to wholesale and retail trade, followed by manufacturing (21.34\%), community, social, and personal services (18\%), construction (14\%), and transport (11\%). The highest absorbing occupational category in 2005/06 was skilled agriculture and fisheries (35.31\%), followed by elementary (unskilled) occupations (19.23\%), craft and related occupations (15.76\%), legislators, senior officials, and managers (11.98\%), and services $(5.37 \%){ }^{2}$

\footnotetext{
${ }^{2}$ Pakistan Labor Force Survey 2005-06, Federal Bureau of Statistics, Islamabad.
} 


\section{Model Specifications}

Human capital theory is widely used in literature as a base for the earnings function of labor. The notion that education and training increases productive capacity similar to physical capital investment goes back at least to Adam Smith (1776). However, the systematic analysis of considering education and training as a form of human capital investment was initiated in the early 1960s. Pioneers of the human capital revolution include Schultz (1961), Mincer (1962), and Becker (1962). According to human capital theory, workers with additional years of schooling can earn relatively more. Similarly, additional years of schooling are expected to enhance the productivity of workers. Since the 1960 s, the neoclassical analysis of 1abor markets has accorded human capital a significant role, especially with regard to wage determination, and this dominates the economic analysis of education. Mincer and Ofek (1982) quantify the effects of depreciation and restoration of human capital by proving empirically the existence and effects of the depreciation of human capital. A study by Psacharopoulos (1994) has important findings on the rate of return to investment in education. He concludes that

Primary education continues to be the number one investment priority in developing countries, educating females is marginally more profitable than educating males, the academic secondary school curriculum is a better investment than the technical/vocational track, and the returns to education obey the same rule as investment in conventional capital, i.e., they decline as investment is expanded [sic] (Psacharopoulos 1994).

This theoretical background provides a base for using Mincer's earning function augmented by required specifications, and can be implied to estimate the supply-side determinants of wages. This can serve further to explore possible differences in returns with different perspectives and the changing role of individual characteristics in affecting wages during trade liberalization.

\section{III.1. Basic Model}

The earnings function in its most basic form was first suggested by Mincer (1974) and has formed the basis for much of the empirical work undertaken in the field of labor economics. The basic model assumes that (i) all individuals are identical, (ii) there are no direct costs of education, (iii) all workers have the same total working life and the same access to capital 
markets, (iv) the market is perfect in terms of access to information, and (v) all educational attainment can be captured in a years of schooling variable $(\mathrm{S})^{3}$. The basic model is given as:

$$
\ln \left(\mathrm{W}_{\mathrm{i}}\right)=\beta_{0}+\beta_{1} \mathrm{~S}_{\mathrm{i}}+\beta_{2} \mathrm{X}_{\mathrm{i}}-\beta_{3} \mathrm{X}_{\mathrm{i}}^{2}+\mathrm{u}_{\mathrm{i}}
$$

where $\mathrm{W}$ is earnings, $\mathrm{S}$ is schooling, $\mathrm{X}$ is experience, $\beta_{1}$ is the rate of return to schooling/education, $\beta_{2}$ is a coefficient reflecting positive return to experience, $\beta_{3}$ is the negative coefficient of the quadratic experience term $\mathrm{X}^{2}$ which produces an age earnings profile that is concave from below, and $\mathrm{u}$ is a residual term. Estimating the rate of return to an additional year in education is important from the policy viewpoint since it answers the question, is it worthwhile investing in human capital or not. The concave age-earnings profile is usually discerned from empirical data on earnings, which suggests increasing earnings with age with declines setting in subsequently as human capital depreciation effects take hold. ${ }^{4}$

\section{III.2. Augmented Mincerian Earnings Function}

The semi-logarithmic form of the Mincerian equation has formed the basis for estimating richer specifications in this study to capture multiple factors, including gender differences in earnings, job location differences in earnings, marital status, differences attributable to different occupations and employment status, and more specifically the inclusion of different mutually exclusive educational qualifications to obtain an annualized rate of return to education. The specification of the model used in the study is given as:

$\ln \left(W_{i}\right)=\beta_{0}+\beta_{1}$ age $_{i}-\beta_{2}$ age $_{i}^{2}+\beta_{3}$ gend $_{i}+\beta_{4}$ techtr $_{i}+\beta_{5}$ prim $_{i}+$ $\beta_{6}$ midd $_{i}+\beta_{7}$ matr $_{i}+\beta_{8}$ interm $_{i}+\beta_{9}$ prof $_{i}+\beta_{10}$ univ $_{i}+\beta_{11}$ pgrad $_{i}+\beta_{12}$ urb $_{i}$ $+\beta_{13}$ casu $_{i}+\beta_{14}$ prate $_{i}+\beta_{15}$ marr $_{i}+\beta_{16}$ wid $_{i}+\beta_{17}$ prof $_{i}+\beta_{18}$ tech $_{i}+\beta_{19}$ clerk $_{i}$ $+\beta_{20} \operatorname{serv}_{i}+\beta_{21}$ skil $_{i}+\beta_{22}$ craft $_{i}+\beta_{23}$ plant $_{i}+\beta_{24}$ elem $_{i}+\mathrm{u}_{\mathrm{i}}$

\footnotetext{
${ }^{3}$ Although the Mincerian Earning Function assumes a homogenous labor market, this assumption does not hold in context of this study. The available data from two LFS does not permit provincial coverage.

${ }^{4}$ The level of experience at which log earnings are maximized can also be obtained from this equation. This can be done by taking differential of earning function with respect to experience $\mathrm{X}$, setting derivative equal to zero and solving for $\mathrm{X}$. This is given as;
}

$$
\frac{\partial \ln \left(\mathrm{W}_{\mathrm{i}}\right)}{\partial X_{\mathrm{i}}}=\beta_{2}+2 \beta_{3} \mathrm{X}_{\mathrm{i}}=0 \quad \Rightarrow \mathrm{X}^{*}=\beta_{2} \div\left[-2 \beta_{3}\right]
$$


The natural $\log$ of hourly wages is used as the dependent variable because hours worked vary over lifecycle and level of education and can also vary across sector. The age and age squared is used as a proxy for experience as data for certain variables required to measure experience directly are not available. Gender is assigned a value of 1 if the individual is male and 0 if female; urban is assigned a value of 1 and rural a value of 0 . Other variables include marital status, employment status, educational qualifications, and occupational categories.' Another point worth mentioning is that the interpretation of estimated effects by introducing dummy variables in semilogarithmic specifications of the model is not straightforward and are interpreted after converting into percentage differential in earnings relative to respective base category as $\left[\mathrm{e}_{\mathrm{vt}}^{\mathrm{b}}-1\right]$ for various estimates.

The annualized rate of return to different educational qualifications can be computed for different qualifications using conventional formulae. For primary and subsequent education levels, the formulae are given as:

$$
\text { Primary: } \frac{\beta_{5}}{\text { PYears }}
$$

$$
\text { Middle: } \frac{\beta 6-\beta 5}{\text { MYears }- \text { PYears }}
$$

Where $\mathrm{P}_{\text {Years }}=$ the total number of years taken to complete a primary qualification; $\mathrm{M}_{\text {Years }}=$ the total number of years taken to complete middle school. Similarly, the return to matric, intermediate and higher degrees can be computed by taking difference of estimates and diving by difference in number of years to respective qualification. The rates of return are computed using the OLS estimates and the sampling variances for these returns are computed in a straightforward manner using the OLS variancecovariance matrix.

The estimated coefficients of occupational categories are an important part of the wage equation. Other than the simple coefficients, relative wages for each occupational category can also be computed with the following formula;

\footnotetext{
${ }^{5}$ The dummy variables are formed in order to measure the qualitative variables and to avoid the 'dummy variable trap', one category in each variable is omitted during estimation. The 'no formal education' is the omitted category among different 'educational qualification', 'regular' employees is the base category in the 'employment status', 'not married' in the 'marital status' variable, and the 'managers' is the base category among different 'occupational groups'.
} 
Related share of occupation $_{\mathrm{j}}=\beta_{j}-\sum_{j=1}^{k} \beta_{j} \times \overline{\text { occu }}_{j}$

Where

$\beta_{j}=$ is estimated coefficient of $\mathbf{j}_{\text {th }}$ occupational category

$\overline{\text { occu }}_{j}=$ mean of wages in the $\mathrm{j}_{\mathrm{th}}$ occupational category

$\sum_{j=1}^{k} \beta_{j} \times \overline{o c c u}_{j}=$ weighted average of all occupational categories

and $\mathbf{j}=1 \ldots \mathrm{k}$, is for nine occupational categories according to their standard classification.

\section{Econometric Methodology}

The econometric methodology used in estimation is defined below.

\section{IV.1. Mean Regression}

First, a pooled regression is carried out using the OLS method applied to the dataset from the LFS 1990/91 and LFS 2005/06. The relevant econometric assumptions are as follows: $u_{i} \sim N\left(0, \sigma^{2}\right)$. In the context of the OLS estimation procedure, the assumption of normality has implications for the testing principles used (i.e., t-tests, F-tests, etc.). The use of the assumption in the context of the Mincerian earnings equation is not without some support. In particular, it is reasonable to assert that labor market earnings follow a log-normal distribution. This distribution has a long rightsided tail to capture the fact that a small number of labor market agents earn exceptionally high wages. It can be shown that, if earnings follow a log-normal distribution, the logarithm of earnings follows a normal distribution, since logging the larger values compresses their size. This provides empirical justification for the use of the semi-logged form in estimation.

\section{IV.2. Quantile Regression}

Recent literature shows that "average" regression can provide a misleading impression as to the variation in the magnitude of the ceteris paribus earnings differences across the wage distribution. There is a rapidly expanding body of literature in economics concerning quantile regression that 
makes a persuasive case for the value of "going beyond models for the conditional mean" as stated by Koenker and Hallock (2001). The quantile regression approach provides a less data-demanding complementary model that can be informative about the impact of covariates at different points of the conditional wage distribution. In the use of a quantile regression model, the focus moves away from the mean to other selected points on the conditional wage distribution and the estimation procedure is formulated in terms of absolute rather than squared errors. The estimator is known as the least absolute deviations estimator.

Estimating a set of conditional quantile functions potentially allows the delineation of a more detailed portrait of the relationship between the conditional wage distribution and the selected covariates. Hence the quantile regression method offers a mechanism for estimating models for the conditional median function and the full range of other conditional quantile functions (i.e., the $10^{\text {th }}, 25^{\text {th }}, 75^{\text {th }}$ or $90^{\text {th }}$ percentile) since it is generally desirable to explore quantile regression other than at the median. In contrast to the OLS approach, the quantile regression procedure is less sensitive to outliers and provides a more robust estimator in the face of departures from normality (Koenker 2005, Koenker and Bassett 1978).

Mosteller and Tukey (1977) best explain it as follows:

What the regression curve does is give a grand summary for the averages of the distributions corresponding to the set of x's. We could go further and compute several different regression curves corresponding to the various percentage points of the distribution and thus get a more complete picture of the set. Ordinarily this is not done, and so regression often gives a rather incomplete picture. Just as the mean gives an incomplete picture of a single distribution, so the regression curve gives a corresponding incomplete picture for a set of distribution.

\section{Selection Bias}

There is potential for a selection bias in the estimated earnings equation as the sample of workers might not represent a random sample drawn from the population. In the context of the mean regression model, Heckman (1979) and Lee (1983) provide well-known solutions. The twostep procedure exploits estimates from a multinomial logit model (MNL) to construct the set of selection correction terms (Lee 1983). Admittedly, the estimation of models with selection effects is always a difficult task. A set 
of instruments is required to identify the parameters of the earnings equation, which includes the selection effects. These identifying instruments are mostly demographic variables and generally exert a significant impact on the current labor force activity of respondents but not on their labor market earnings. In simple words, the instruments selected should influence employment status but not wage. This identification proved a hurdle in handling selection bias in this study due to the lack of proper instruments in the Labor Force Surveys. The issue is usually addressed by using the generalized framework popularized by Lee (1983) in general studies of wage differentials and decomposition using labor force survey data and traditionally reporting results both with and without correction for the selectivity bias (Gyourko and Tracy 1988). However, only one study (Dutta 2007) appears to address this issue while dealing with trade and wage linkages and controlling for individual characteristics. In our case, there is no variable in the datasets that might be used as an instrumental variable in a multinomial function, which appeared to be insignificant for wage functions.

\section{Data Description}

The data used in this study is cross-sectional and is drawn from the nationally representative LFS for Pakistan for 2005/06, a period specified as post-trade liberalization, and for 1990/91, the initial year of trade liberalization. Hence, we compare the behavior of different wage determinants across two ends. No data were available on household wages for the period before 1990/91. The working sample used is based on wage employment and comprises a total of 8,006 workers for $1990 / 91$ and 9,894 for $2005 / 06$, once missing values and unusable observations are discarded. Data collection for the LFS is spread over four quarters of the year in order to capture any seasonal variations in activity. The survey covers all urban and rural areas of the four provinces of Pakistan as defined by the 1998 population census. It excludes the Federally Administered Tribal Areas (FATA), military restricted areas, and protected areas of NWFP. These exclusions are not seen as significant since the relevant areas constitute about $3 \%$ of the total population of Pakistan.

Table 1 provides the summary statistics and definitions of variables used in our analysis. The natural log of real hourly wages (1nwph) is used as the dependent variable. Hourly wages are expressed in Pakistan rupees and calculated by dividing weekly earnings by the number of hours worked per week. For estimation purposes, wages are converted into real wages to make comparisons consistent across years. Real wages are obtained by deflating nominal wages to $2000 / 01$ prices using the nationally representative 
consumer price index (CPI). The wages reported in LFS are basically the amount of money earned by persons in cash or in kind and bonuses received and are reported net, after deducting social security contributions and pensions and income tax. The average real wages have increased over the period studied. The standard deviation is quite high among all workers.

From a human capital perspective, age and its quadratic are used in the model to examine the wage and age relationship. The age of working employees is restricted, starting from 15 years. The average wage for employees in 2005-06 is 35 years. The variable gender (gend) is measured by specifying a dummy with value 1 for males, and shows that labor force participation is considerably higher for males than females, i.e., 0.92 for $1990 / 91$ and 0.88 for $2005 / 06$, though female participation has increased over time. Overall, the participation rate rose from $30.4 \%$ in $2003 / 04$ to $32.2 \%$ in $2005 / 06$ - more for women belonging to rural areas than men residing in urban areas. The inclusion of women in the analysis is to examine the gender gap during the period of trade liberalization in wages.

Marital status is divided into three mutually exclusive categories: (i) not married (ntm), (ii) married (marr), and (iii) widowed/divorced (wid). The majority of workers belong to the second category in our sample. Technical or vocational training (techtr) is a minor category, i.e., 0.13 for 1990/91 which declined to 0.03 in $2005 / 06$. The settlement type within which the individual resides is captured by a binary control variable for residing in an urban area. The majority of labor is concentrated in urban areas.

A detailed disaggregation of educational qualifications is used to facilitate the computation of the private rate of returns to these qualifications. Eight educational categories are used for this purpose. The majority of labor has no formal education (nfed) (0.293), followed by primary (prim) (0.17) and matriculation (matr) (0.164) level of education in 2005/06.

Employment status, another determinant of the earnings function, is divided into three types: (i) regular employees with fixed wages (regul), (ii) casual paid employees (casu), and (iii) paid workers by piece rate or work performed (prate)). In 2005/06, job concentration increased for casual workers $(0.057$ to 0.224$)$ and decreased for regular workers $(0.908$ to 0.581$)$ relative to $1990 / 91$.

Occupation is another important factor in the earnings function. Nine one-digit occupational categories are selected, defined according to the Pakistan standard classification of occupations based on the International 
Standard Classification of Occupations of 1988 (ISCO_88). ${ }^{6}$ Overall, labor was mostly concentrated in the clerical $(0.22)$ and services sectors $(0.20)$ in $1990 / 91$ and in the elementary (0.262) and craft sectors (0.256) in 2005/06. The number of skilled agricultural and fishery workers has remained nominal in both years.

${ }^{6}$ The Revised International Classification of Occupation (ISCO_88), ILO, Geneva, 1990. 
Table-1: Summary Statistics

\begin{tabular}{|c|c|c|c|}
\hline Variable & Definition & $\begin{array}{c}\text { Mean } \\
(1990 / 91) \\
\end{array}$ & $\begin{array}{c}\text { Mean } \\
(2005 / 06) \\
\end{array}$ \\
\hline $\begin{array}{l}\text { Log Earnings: } \\
\text { lnwph }\end{array}$ & Natural log of the hourly wage & $\begin{array}{c}2.02 \\
(0.670)\end{array}$ & $\begin{array}{c}3.28 \\
(0.802)\end{array}$ \\
\hline Age & Age of individual in years & $\begin{array}{c}33 \\
(11.06)\end{array}$ & $\begin{array}{c}35 \\
(11.12)\end{array}$ \\
\hline Gender: Gend & $=1$ if individual is male; $=0$, otherwise & 0.92 & 0.88 \\
\hline $\begin{array}{l}\text { Technical } \\
\text { Training: Techtr }\end{array}$ & $\begin{array}{l}=1 \text { if individual has technical or } \\
\text { vocational training; }=0 \text {, otherwise }\end{array}$ & 0.135 & 0.03 \\
\hline $\begin{array}{l}\text { Marital Status: } \\
\text { Ntm }\end{array}$ & $\begin{array}{l}=1 \text { if individual is not married; }=0 \text {, } \\
\text { otherwise }\end{array}$ & 0.27 & 0.25 \\
\hline Marr & $\begin{array}{l}=1 \text { if individual is married; }=0 \text {, } \\
\text { otherwise }\end{array}$ & 0.70 & 0.73 \\
\hline Wid & $\begin{array}{l}=1 \text { if individual is widowed or divorced; } \\
=0, \text { otherwise }\end{array}$ & 0.02 & 0.021 \\
\hline Education: Nfed & $\begin{array}{l}=1 \text { if individual has no formal } \\
\text { education; }=0, \text { otherwise }\end{array}$ & 0.29 & 0.293 \\
\hline Prim & $\begin{array}{l}=1 \text { if individual has completed initial } \\
\text { five years of education i.e., primary but } \\
\text { below middle; }=0 \text {, otherwise }\end{array}$ & 0.147 & 0.17 \\
\hline Midd & $\begin{array}{l}=1 \text { if individual has completed initial } \\
\text { eight years of education i.e., middle } \\
\text { but below matriculation; }=0 \text {, } \\
\text { otherwise }\end{array}$ & 0.106 & 0.107 \\
\hline Matr & $\begin{array}{l}=1 \text { if individual has completed initial } \\
\text { ten years of education i.e., } \\
\text { matriculation but below intermediate; } \\
=0 \text {, otherwise }\end{array}$ & 0.20 & 0.164 \\
\hline Interm & $\begin{array}{l}=1 \text { if individual has completed two } \\
\text { years for college education i.e., } \\
\text { intermediate but below post } \\
\text { intermediate; }=0 \text {, otherwise }\end{array}$ & 0.097 & 0.092 \\
\hline Prof & $\begin{array}{l}=1 \text { if individual has professional degree } \\
\text { (doctors, engineers); }=0 \text {, otherwise }\end{array}$ & 0.03 & 0.021 \\
\hline Univ & $\begin{array}{l}=1 \text { if individual has university degree; } \\
=0, \text { otherwise }\end{array}$ & 0.078 & 0.147 \\
\hline
\end{tabular}




\begin{tabular}{|c|c|c|c|}
\hline Pgrad & $\begin{array}{l}\text { = } 1 \text { if individual has post graduation } \\
\text { qualification }(\mathrm{M}-\mathrm{Phil}, \mathrm{PhD}) ;=0 \\
\text { otherwise }\end{array}$ & 0.037 & 0.003 \\
\hline $\begin{array}{l}\text { Employment } \\
\text { Status: Regul }\end{array}$ & $\begin{array}{l}=1 \text { if individual is regular paid } \\
\text { employee with fixed wages; }=0 \text {, } \\
\text { otherwise }\end{array}$ & 0.908 & 0.581 \\
\hline Casu & $\begin{array}{l}=1 \text { if individual is casual paid employee; } \\
=0, \text { otherwise }\end{array}$ & 0.057 & 0.224 \\
\hline Prate & $\begin{array}{l}=1 \text { if individual is a paid worker by } \\
\text { piece rate service performed; }=0 \text {, } \\
\text { otherwise }\end{array}$ & 0.034 & 0.194 \\
\hline $\begin{array}{l}\text { Urbanization: } \\
\text { Urb }\end{array}$ & $\begin{array}{l}=1 \text { if individual is living in urban area; } \\
=0, \text { otherwise }\end{array}$ & 0.71 & 0.66 \\
\hline $\begin{array}{l}\text { Profession: } \\
\text { Manager }\end{array}$ & $\begin{array}{l}=1 \text { if individual is in this one-digit } \\
\text { occupation group; = } 0 \text {, otherwise }\end{array}$ & 0.04 & 0.037 \\
\hline Professionals & $\begin{array}{l}=1 \text { if individual is in this one-digit } \\
\text { occupation group; = } 0 \text {, otherwise }\end{array}$ & 0.15 & 0.047 \\
\hline Technician & $\begin{array}{l}=1 \text { if individual is in this one-digit } \\
\text { occupation group; }=0 \text {, otherwise }\end{array}$ & 0.05 & 0.175 \\
\hline Clerk & $\begin{array}{l}=1 \text { if individual is in this one-digit } \\
\text { occupation group; = } 0 \text {, otherwise }\end{array}$ & 0.22 & 0.073 \\
\hline Services & $\begin{array}{l}=1 \text { if individual is in this one-digit } \\
\text { occupation group; = } 0 \text {, otherwise }\end{array}$ & 0.20 & 0.092 \\
\hline Skilled & $\begin{array}{l}=1 \text { if individual is in this one-digit } \\
\text { occupation group; = } 0 \text {, otherwise }\end{array}$ & 0.04 & 0.010 \\
\hline Craft & $\begin{array}{l}=1 \text { if individual is in this one-digit } \\
\text { occupation group; = } 0 \text {, otherwise }\end{array}$ & 0.06 & 0.256 \\
\hline Plant & $\begin{array}{l}=1 \text { if individual is in this one-digit } \\
\text { occupation group; = } 0 \text {, otherwise }\end{array}$ & 0.09 & 0.045 \\
\hline Elementary & $\begin{array}{l}=1 \text { if individual is in this one-digit } \\
\text { occupation group; = } 0 \text {, otherwise }\end{array}$ & 0.14 & 0.262 \\
\hline Sample Size & & 8,006 & 9,894 \\
\hline
\end{tabular}

Notes: Average values for continuous measures and sample proportion for discrete measures are reported. Standard deviations are also reported for continuous variables in parentheses. 


\section{Empirical Results and Interpretation}

The following section interprets the earning function estimates from different perspectives.

\section{Earning Function Estimates and Trade Liberalization}

Table 2 provides earnings equation estimates for the LFS 1990/91. The results are reported for mean and quantile regressions. Quantile regression results are reported for the $10^{\text {th }}, 25^{\text {th }}, 50^{\text {th }}, 75^{\text {th }}$ and $90^{\text {th }}$ quantiles. Similarly, Table 3 provides results for the LFS 2005/06. By and large, the estimates appear to have similar signs for both years with high statistical precision (low standard errors). All models fit well with most of the variables appearing statistically significant at a $1 \%$ level of significance and reasonably high values for $\mathrm{R}^{2}$ and F-stat, keeping in view heterogeneity across workers. The earnings equation explains the relatively high proportion (40\%) of total variation in earnings among individuals. Multicolinearity was checked for the models with the help of a variance inflation factor (VIF) and no variable reported a VIF value of more than $10 .^{7}$ This shows that multicolinearity is not a problem. Heteroskedasticity was checked and adjusted for in the models by applying the White-heteroskedastic technique. Now we turn to the interpretation of these results.

\section{Human Capital Factors}

As typically reported in studies of earnings functions, age enters as positively significant while its quadratic term enters as negatively significant in the earnings equation, following age depletion effects. A concave ageearnings profile suggests that wage increases with age at a decreasing rate and that this is due to the human capital depletion effect. The age-earnings profile peaks at 53 years of age in both years. It is worth noting that the average age at which earnings are maximized is similar in both years. No change in wage determination regarding age occurred across the periods; rather the magnitude remained the same for age and age squared.

The quantile regression findings for age and age squared confirm the nonlinear age-earnings profiles for both years. The estimates for age at median are broadly in conformity with the mean regression and this could be taken to imply that outliers exert little influence on mean estimates.

\footnotetext{
${ }^{7}$ A rule of thumb is provided by David G. Kleinbaum, Lawrence L. Kupper and Keith E. Muller (1988), “Applied Regression Analysis and other Multivariate Methods”, $2^{\text {nd }}$ ed., PWS-Kent, Boston, Mass, p. 210.
} 
The variable technical training yields a negatively significant finding for the year 2005/06 whereas it is statistically insignificant for 1990/91. The coefficient for 2005/06 shows that technically trained workers earn 9\% less than workers with no training. The quantile regression estimates provide a better insight: in the lowest paid jobs located in the $10^{\text {th }}$ and $25^{\text {th }}$ percentiles of the conditional wage distribution, technically trained workers earn significantly less than nontrained workers, while in the highest paid jobs in the $75^{\text {th }}$ and $90^{\text {th }}$ percentiles the difference is statistically insignificant in $2005 / 06$. It implies that technically trained workers getting the lowest paid jobs earn significantly less than nontrained workers. Their training does not provide them highly paid jobs nor does it give them a wage premium compared with nontrained workers. Comparatively, in the highest paid jobs, trained workers are no more disadvantaged than nontrained workers, and both earn similar wages (no statistical difference). In contrast, for 1990/91 at the top-end of wage distribution, the return to trained workers is statistically positively significant and insignificant in low-paid jobs in the $10^{\text {th }}, 25^{\text {th }}$, and $50^{\text {th }}$ quantiles. This postulates that technical training in $1990 / 91$ rewarded workers with higher wages and high-paid jobs due to their training while trained workers in the lowest paid jobs were not getting particularly different wages than nontrained workers and this difference disappeared over time. These findings can be supported by the argument that technical infusion during trade liberalization demands the type of training that workers have not been able to acquire over time. Trade liberalization has not provided them wage premiums, even with their technical knowhow, because their training is not at par with the demands of globalization, thus barring trained workers from the potential benefits of free trade. 
Table-2: Earnings Function Estimates based on Pooled Data for Pakistan (1990/91)

\begin{tabular}{|c|c|c|c|c|c|c|}
\hline \multirow[t]{2}{*}{ Variables } & \multirow{2}{*}{$\begin{array}{c}\text { Mean } \\
\text { Regression }\end{array}$} & \multicolumn{5}{|c|}{ Quantile Regression } \\
\hline & & $10^{\text {th }}$ & $25^{\text {th }}$ & $50^{\text {th }}$ & $75^{\text {th }}$ & $90^{\text {th }}$ \\
\hline Constant & $\begin{array}{l}1.4568 * \\
(0.076)\end{array}$ & $\begin{array}{c}0.58^{*} \\
(0.129)\end{array}$ & $\begin{array}{l}1.24^{*} \\
(0.088)\end{array}$ & $\begin{array}{c}1.71 * \\
(0.072)\end{array}$ & $\begin{array}{c}2.01 * \\
(0.074)\end{array}$ & $\begin{array}{c}2.14^{*} \\
(0.115)\end{array}$ \\
\hline Age & $\begin{array}{l}0.032 * \\
(0.004)\end{array}$ & $\begin{array}{l}0.049^{*} \\
(0.006)\end{array}$ & $\begin{array}{l}0.038^{*} \\
(0.004)\end{array}$ & $\begin{array}{c}0.025^{*} \\
(0.004)\end{array}$ & $\begin{array}{l}0.020^{*} \\
(0.003)\end{array}$ & $\begin{array}{l}0.021^{*} \\
(0.005)\end{array}$ \\
\hline $\operatorname{Age}^{2}$ & $\begin{array}{l}-0.0003 * \\
(0.00005)\end{array}$ & $\begin{array}{l}-0.0006^{*} \\
(0.00008)\end{array}$ & $\begin{array}{l}-0.0004^{*} \\
(0.00006)\end{array}$ & $\begin{array}{l}-0.0002 * \\
(0.00005)\end{array}$ & $\begin{array}{l}-0.0002^{*} \\
(0.00004)\end{array}$ & $\begin{array}{l}-0.0002 * \\
(0.00007)\end{array}$ \\
\hline Gend & $\begin{array}{l}0.147 * \\
(0.025)\end{array}$ & $\begin{array}{l}0.227 * \\
(0.040)\end{array}$ & $\begin{array}{l}0.129 * \\
(0.027)\end{array}$ & $\begin{array}{l}0.100 * \\
(0.022)\end{array}$ & $\begin{array}{l}0.100 * \\
(0.023)\end{array}$ & $\begin{array}{l}0.091 * \\
(0.032)\end{array}$ \\
\hline Techtr & $\begin{array}{c}0.020 \\
(0.022)\end{array}$ & $\begin{array}{l}-0.027 \\
(0.034)\end{array}$ & $\begin{array}{l}0.0041 \\
(0.023)\end{array}$ & $\begin{array}{c}0.010 \\
(0.019)\end{array}$ & $\begin{array}{l}0.043 * * \\
(0.019)\end{array}$ & $\begin{array}{c}0.058 * * \\
(0.029)\end{array}$ \\
\hline $\begin{array}{l}\text { Human } \\
\text { Capital: } \\
\text { Prim }\end{array}$ & $\begin{array}{l}0.050 * \\
(0.019)\end{array}$ & & & $\begin{array}{c}0.032^{* * *} \\
(0.018)\end{array}$ & $\begin{array}{c}0.047^{* *} \\
(0.019)\end{array}$ & $\begin{array}{c}0.0583^{* *} \\
(0.028)\end{array}$ \\
\hline Midd & $\begin{array}{l}0.169 * \\
(0.020)\end{array}$ & $\begin{array}{l}0.238^{*} \\
(0.036)\end{array}$ & $\begin{array}{l}0.137^{*} \\
(0.025)\end{array}$ & $\begin{array}{l}0.121 * \\
(0.021)\end{array}$ & $\begin{array}{l}0.136^{*} \\
(0.021)\end{array}$ & $\begin{array}{l}0.145^{*} \\
(0.032)\end{array}$ \\
\hline Matr & $\begin{array}{l}0.300 * \\
(0.019)\end{array}$ & $\begin{array}{c}0.40^{*} \\
(0.034)\end{array}$ & $\begin{array}{l}0.279 * \\
(0.023)\end{array}$ & $\begin{array}{l}0.233^{*} \\
(0.018)\end{array}$ & $\begin{array}{l}0.233^{*} \\
(0.019)\end{array}$ & $\begin{array}{l}0.256^{*} \\
(0.028)\end{array}$ \\
\hline Interm & $\begin{array}{l}0.443 * \\
(0.023)\end{array}$ & $\begin{array}{l}0.514^{*} \\
(0.043)\end{array}$ & $\begin{array}{l}0.413^{*} \\
(0.028)\end{array}$ & $\begin{array}{l}0.380^{*} \\
(0.024)\end{array}$ & $\begin{array}{l}0.356^{*} \\
(0.025)\end{array}$ & $\begin{array}{l}0.454^{*} \\
(0.038)\end{array}$ \\
\hline Prof & $\begin{array}{l}0.863^{*} \\
(0.036)\end{array}$ & $\begin{array}{l}0.853^{*} \\
(0.073)\end{array}$ & $\begin{array}{l}0.753^{*} \\
(0.048)\end{array}$ & $\begin{array}{l}0.801^{*} \\
(0.038)\end{array}$ & $\begin{array}{l}0.862^{*} \\
(0.038)\end{array}$ & $\begin{array}{l}0.928^{*} \\
(0.058)\end{array}$ \\
\hline Univ & $\begin{array}{l}0.643 * \\
(0.027)\end{array}$ & $\begin{array}{l}0.644^{*} \\
(0.047)\end{array}$ & $\begin{array}{l}0.538^{*} \\
(0.032)\end{array}$ & $\begin{array}{l}0.568 * \\
(0.027)\end{array}$ & $\begin{array}{l}0.622 * \\
(0.027)\end{array}$ & $\begin{array}{l}0.720 * \\
(0.042)\end{array}$ \\
\hline Pgrad & $\begin{array}{l}0.883^{*} \\
(0.037)\end{array}$ & $\begin{array}{l}0.715^{*} \\
(0.062)\end{array}$ & $\begin{array}{l}0.722^{*} \\
(0.042)\end{array}$ & $\begin{array}{l}0.804^{*} \\
(0.035)\end{array}$ & $\begin{array}{l}0.905^{*} \\
(0.036)\end{array}$ & $\begin{array}{c}1.07^{*} \\
(0.054)\end{array}$ \\
\hline $\begin{array}{l}\text { Job } \\
\text { Location: } \\
\text { Urb }\end{array}$ & $\begin{array}{l}0.112 * \\
(0.014)\end{array}$ & $\begin{array}{l}0.142 * \\
(0.023)\end{array}$ & $\begin{array}{l}0.084^{*} \\
(0.016)\end{array}$ & $\begin{array}{l}0.086 * \\
(0.013)\end{array}$ & $\begin{array}{l}0.095 * \\
(0.014)\end{array}$ & $\begin{array}{l}0.113 * \\
(0.019)\end{array}$ \\
\hline $\begin{array}{l}\text { Job } \\
\text { Nature: } \\
\text { Casu }\end{array}$ & $\begin{array}{c}-0.264^{*} \\
(0.031)\end{array}$ & $\begin{array}{c}-0.461 * \\
(0.044)\end{array}$ & $\begin{array}{c}-0.289^{*} \\
(0.030)\end{array}$ & $\begin{array}{c}-0.230^{*} \\
(0.025)\end{array}$ & $\begin{array}{c}-0.171 * \\
(0.025)\end{array}$ & $\begin{array}{c}-0.084^{* *} \\
(0.038)\end{array}$ \\
\hline Prate & $\begin{array}{c}-0.391 * \\
(0.049)\end{array}$ & $\begin{array}{c}-0.766^{*} \\
(0.057)\end{array}$ & $\begin{array}{l}-0.47^{*} \\
(0.040)\end{array}$ & $\begin{array}{l}-0.335^{*} \\
(0.032)\end{array}$ & $\begin{array}{l}-0.136^{*} \\
(0.033)\end{array}$ & $\begin{array}{c}-0.107^{* *} \\
(0.049)\end{array}$ \\
\hline
\end{tabular}




\begin{tabular}{|c|c|c|c|c|c|c|}
\hline $\begin{array}{l}\text { Marital } \\
\text { Status: } \\
\text { Marr }\end{array}$ & $\begin{array}{l}0.069^{*} \\
(0.017)\end{array}$ & $\begin{array}{l}0.089 * \\
(0.029)\end{array}$ & $\begin{array}{l}0.083^{*} \\
(0.020)\end{array}$ & $\begin{array}{l}0.073^{*} \\
(0.017)\end{array}$ & $\begin{array}{l}0.081 * \\
(0.017)\end{array}$ & $\begin{array}{c}0.058 * * \\
(0.026)\end{array}$ \\
\hline Wid & $\begin{array}{l}-0.044 \\
(0.049)\end{array}$ & $\begin{array}{l}-0.103 \\
(0.077)\end{array}$ & $\begin{array}{c}-0.109^{* *} \\
(0.052)\end{array}$ & $\begin{array}{l}-0.054 \\
(0.043)\end{array}$ & $\begin{array}{l}0.0004 \\
(0.044)\end{array}$ & $\begin{array}{c}0.007 \\
(0.065)\end{array}$ \\
\hline $\begin{array}{l}\text { Profession } \\
\text { s: Prof }\end{array}$ & $\begin{array}{l}-0.44^{*} \\
(0.034)\end{array}$ & $\begin{array}{c}-0.471 * \\
(0.062)\end{array}$ & $\begin{array}{c}-0.488^{*} \\
(0.041)\end{array}$ & $\begin{array}{l}-0.470^{*} \\
(0.034)\end{array}$ & $\begin{array}{l}-0.486^{*} \\
(0.035)\end{array}$ & $\begin{array}{l}-0.445^{*} \\
(0.053)\end{array}$ \\
\hline Tech & $\begin{array}{c}-0.352^{*} \\
(0.039)\end{array}$ & $\begin{array}{c}-0.431 * \\
(0.073)\end{array}$ & $\begin{array}{c}-0.456^{*} \\
(0.049)\end{array}$ & $\begin{array}{c}-0.393 * \\
(0.040)\end{array}$ & $\begin{array}{c}-0.345^{*} \\
(0.041)\end{array}$ & $\begin{array}{c}-0.352^{*} \\
(0.061)\end{array}$ \\
\hline Clerk & $\begin{array}{l}-0.57^{*} \\
(0.032)\end{array}$ & $\begin{array}{c}-0.556^{*} \\
(0.060)\end{array}$ & $\begin{array}{c}-0.607^{*} \\
(0.040)\end{array}$ & $\begin{array}{l}-0.583^{*} \\
(0.034)\end{array}$ & $\begin{array}{l}-0.611^{*} \\
(0.034)\end{array}$ & $\begin{array}{l}-0.565^{*} \\
(0.052)\end{array}$ \\
\hline Serv & $\begin{array}{c}-0.749^{*} \\
(0.035)\end{array}$ & $\begin{array}{c}-0.866^{*} \\
(0.064)\end{array}$ & $\begin{array}{c}-0.842 * \\
(0.043)\end{array}$ & $\begin{array}{l}-0.767^{*} \\
(0.035)\end{array}$ & $\begin{array}{c}-0.771 * \\
(0.036)\end{array}$ & $\begin{array}{l}-0.691 * \\
(0.057)\end{array}$ \\
\hline Skill & $\begin{array}{c}-0.786^{*} \\
(0.048)\end{array}$ & $\begin{array}{l}-1.03^{*} \\
(0.080)\end{array}$ & $\begin{array}{c}-0.988^{*} \\
(0.054)\end{array}$ & $\begin{array}{c}-0.771^{*} \\
(0.041)\end{array}$ & $\begin{array}{c}-0.709^{*} \\
(0.046)\end{array}$ & $\begin{array}{c}-0.681 * \\
(0.070)\end{array}$ \\
\hline Craft & $\begin{array}{l}-0.566^{*} \\
(0.042)\end{array}$ & $\begin{array}{c}-0.650^{*} \\
(0.074)\end{array}$ & $\begin{array}{c}-0.665^{*} \\
(0.049)\end{array}$ & $\begin{array}{l}-0.646^{*} \\
(0.041)\end{array}$ & $\begin{array}{l}-0.617^{*} \\
(0.042)\end{array}$ & $\begin{array}{l}-0.558^{*} \\
(0.065)\end{array}$ \\
\hline Plant & $\begin{array}{l}-0.511^{*} \\
(0.037)\end{array}$ & $\begin{array}{c}-0.562 * \\
(0.069)\end{array}$ & $\begin{array}{c}-0.583^{*} \\
(0.047)\end{array}$ & $\begin{array}{l}-0.550^{*} \\
(0.038)\end{array}$ & $\begin{array}{l}-0.578^{*} \\
(0.039)\end{array}$ & $\begin{array}{c}-0.541^{*} \\
(0.061)\end{array}$ \\
\hline Elem & $\begin{array}{c}-0.561 * \\
(0.036)\end{array}$ & $\begin{array}{l}-0.635^{*} \\
(0.067)\end{array}$ & $\begin{array}{c}-0.654^{*} \\
(0.045)\end{array}$ & $\begin{array}{l}-0.589^{*} \\
(0.037)\end{array}$ & $\begin{array}{l}-0.594^{*} \\
(0.038)\end{array}$ & $\begin{array}{l}-0.561^{*} \\
(0.058)\end{array}$ \\
\hline $\begin{array}{l}\mathrm{R}^{2} / \text { Pseudo } \\
\mathrm{R}^{2}\end{array}$ & 0.43 & 0.25 & 0.24 & 0.26 & 0.31 & 0.36 \\
\hline F-statistic & 237.57 & - & - & - & - & - \\
\hline $\mathrm{N}$ & 8,006 & 8,006 & 8,006 & 8,006 & 8,006 & 8,006 \\
\hline
\end{tabular}

Notes: 1) The standard errors are given in parentheses.

2) The standard errors are robust to heteroskedasticity.

$3) *, * *, * * *$ denote statistical significance at the $1 \%, 5 \%$ and $10 \%$ level respectively using two-tailed test.

4) The base categories are omitted from the model to avoid dummy variable trap. 
Table-3: Earnings Function Estimates based on Pooled Data for Pakistan (2005/06)

\begin{tabular}{|c|c|c|c|c|c|c|}
\hline \multirow[t]{2}{*}{ Variables } & \multirow{2}{*}{$\begin{array}{c}\text { Mean } \\
\text { Regression }\end{array}$} & \multicolumn{5}{|c|}{ Quantile Regression } \\
\hline & & $10^{\text {th }}$ & $25^{\text {th }}$ & $50^{\text {th }}$ & $75^{\text {th }}$ & $90^{\text {th }}$ \\
\hline Constant & $\begin{array}{l}0.914^{*} \\
(0.085)\end{array}$ & $\begin{array}{l}-0.601^{*} \\
(0.153)\end{array}$ & $\begin{array}{l}0.369^{*} \\
(0.093)\end{array}$ & $\begin{array}{l}1.118^{*} \\
(0.069)\end{array}$ & $\begin{array}{c}1.75 * \\
(0.079)\end{array}$ & $\begin{array}{c}2.26^{*} \\
(0.106)\end{array}$ \\
\hline Age & $\begin{array}{l}0.032 * \\
(0.004)\end{array}$ & $\begin{array}{l}0.053^{*} \\
(0.008)\end{array}$ & $\begin{array}{l}0.036^{*} \\
(0.005)\end{array}$ & $\begin{array}{l}0.030^{*} \\
(0.004)\end{array}$ & $\begin{array}{l}0.022^{*} \\
(0.004)\end{array}$ & $\begin{array}{c}0.010 * * * \\
(0.005)\end{array}$ \\
\hline $\mathrm{Age}^{2}$ & $\begin{array}{l}-0.0003^{*} \\
(0.00005)\end{array}$ & $\begin{array}{c}-0.0006^{*} \\
(0.0001)\end{array}$ & $\begin{array}{c}-0.0003^{*} \\
(0.00006)\end{array}$ & $\begin{array}{c}-0.0002 * \\
(0.00005)\end{array}$ & $\begin{array}{c}-0.0001^{*} \\
(0.00005)\end{array}$ & $\begin{array}{c}0.0000 \\
(0.00007)\end{array}$ \\
\hline Gend & $\begin{array}{c}0.249^{*} \\
(0.02)\end{array}$ & $\begin{array}{c}0.52 * \\
(0.037)\end{array}$ & $\begin{array}{l}0.378^{*} \\
(0.022)\end{array}$ & $\begin{array}{c}0.23 * \\
(0.017)\end{array}$ & $\begin{array}{l}0.127^{*} \\
(0.020)\end{array}$ & $\begin{array}{c}0.031 \\
(0.027)\end{array}$ \\
\hline Techtr & $\begin{array}{c}-0.096 * * \\
(0.039)\end{array}$ & $\begin{array}{l}-0.189 * \\
(0.069)\end{array}$ & $\begin{array}{c}-0.096^{* *} \\
(0.042)\end{array}$ & $\begin{array}{l}-0.053 \\
(0.032)\end{array}$ & $\begin{array}{l}-0.053 \\
(0.037)\end{array}$ & $\begin{array}{l}-0.063 \\
(0.050)\end{array}$ \\
\hline $\begin{array}{l}\text { Human } \\
\text { Capital: } \\
\text { Prim }\end{array}$ & $\begin{array}{l}0.514^{*} \\
(0.018)\end{array}$ & $\begin{array}{c}0.023 \\
(0.035)\end{array}$ & $\begin{array}{c}0.039 * * * \\
(0.021)\end{array}$ & $\begin{array}{l}0.051^{*} \\
(0.02)\end{array}$ & $\begin{array}{c}0.030 \\
(0.018)\end{array}$ & $\begin{array}{c}0.045^{* * * *} \\
(0.025)\end{array}$ \\
\hline Midd & $\begin{array}{l}0.126^{*} \\
(0.022)\end{array}$ & $\begin{array}{l}0.104^{*} \\
(0.041)\end{array}$ & $\begin{array}{l}0.125^{*} \\
(0.025)\end{array}$ & $\begin{array}{l}0.125^{*} \\
(0.019)\end{array}$ & $\begin{array}{c}0.066 \\
(0.049)\end{array}$ & $\begin{array}{l}0.114^{*} \\
(0.029)\end{array}$ \\
\hline Matr & $\begin{array}{l}0.218^{*} \\
(0.022)\end{array}$ & $\begin{array}{l}0.266^{*} \\
(0.042)\end{array}$ & $\begin{array}{l}0.215^{*} \\
(0.026)\end{array}$ & $\begin{array}{l}0.196^{*} \\
(0.019)\end{array}$ & $\begin{array}{l}0.146^{*} \\
(0.022)\end{array}$ & $\begin{array}{l}0.195 * \\
(0.029)\end{array}$ \\
\hline Interm & $\begin{array}{l}0.381 * \\
(0.027)\end{array}$ & $\begin{array}{l}0.453^{*} \\
(0.056)\end{array}$ & $\begin{array}{l}0.41^{*} \\
(0.03)\end{array}$ & $\begin{array}{l}0.344^{*} \\
(0.025)\end{array}$ & $\begin{array}{l}0.280^{*} \\
(0.028)\end{array}$ & $\begin{array}{l}0.300^{*} \\
(0.038)\end{array}$ \\
\hline Prof & $\begin{array}{l}0.716^{*} \\
(0.055)\end{array}$ & $\begin{array}{l}0.812^{*} \\
(0.102)\end{array}$ & $\begin{array}{l}0.721^{*} \\
(0.062)\end{array}$ & $\begin{array}{l}0.626^{*} \\
(0.045)\end{array}$ & $\begin{array}{l}0.549 * \\
(0.051)\end{array}$ & $\begin{array}{l}0.614^{*} \\
(0.068)\end{array}$ \\
\hline Univ & $\begin{array}{l}0.594^{*} \\
(0.029)\end{array}$ & $\begin{array}{l}0.594^{*} \\
(0.058)\end{array}$ & $\begin{array}{l}0.566^{*} \\
(0.034)\end{array}$ & $\begin{array}{l}0.522 * \\
(0.024)\end{array}$ & $\begin{array}{l}0.498^{*} \\
(0.028)\end{array}$ & $\begin{array}{l}0.586^{*} \\
(0.038)\end{array}$ \\
\hline Pgrad & $\begin{array}{l}1.150^{*} \\
(0.158)\end{array}$ & $\begin{array}{l}1.108^{*} \\
(0.189)\end{array}$ & $\begin{array}{l}1.32^{*} \\
(0.128\end{array}$ & $\begin{array}{c}1.07 * \\
(0.099)\end{array}$ & $\begin{array}{l}1.144^{*} \\
(0.117)\end{array}$ & $\begin{array}{l}1.227^{*} \\
(0.138)\end{array}$ \\
\hline $\begin{array}{l}\text { Job } \\
\text { Location: } \\
\text { Urb }\end{array}$ & $\begin{array}{c}0.009 \\
(0.013)\end{array}$ & $\begin{array}{c}0.038 \\
(0.025)\end{array}$ & $\begin{array}{l}0.040^{*} \\
(0.015)\end{array}$ & $\begin{array}{c}0.007 \\
(0.011)\end{array}$ & $\begin{array}{c}0.0157 \\
(0.0133)\end{array}$ & $\begin{array}{c}0.038 * * \\
(0.017)\end{array}$ \\
\hline $\begin{array}{l}\text { Job Nature: } \\
\text { Casu }\end{array}$ & $\begin{array}{c}-0.295^{*} \\
(0.019)\end{array}$ & $\begin{array}{l}-0.295^{*} \\
(0.041)\end{array}$ & $\begin{array}{l}-0.344^{*} \\
(0.023)\end{array}$ & $\begin{array}{l}-0.33 * \\
(0.017)\end{array}$ & $\begin{array}{c}-0.278^{*} \\
(0.018)\end{array}$ & $\begin{array}{l}-0.221^{*} \\
(0.025)\end{array}$ \\
\hline Prate & $\begin{array}{c}-0.372 * \\
(0.022)\end{array}$ & $\begin{array}{c}-0.378^{*} \\
(0.046)\end{array}$ & $\begin{array}{c}-0.427^{*} \\
(0.025)\end{array}$ & $\begin{array}{c}-0.442 * \\
(0.019)\end{array}$ & $\begin{array}{c}-0.382 * \\
(0.021)\end{array}$ & $\begin{array}{c}-0.269 * \\
(0.028)\end{array}$ \\
\hline
\end{tabular}




\begin{tabular}{|c|c|c|c|c|c|c|}
\hline $\begin{array}{l}\text { Marital } \\
\text { Status: } \\
\text { Marr }\end{array}$ & $\begin{array}{c}0.041^{* * *} \\
(0.021)\end{array}$ & $\begin{array}{c}0.078^{* *} \\
(0.04)\end{array}$ & $\begin{array}{l}0.033 \\
(0.02)\end{array}$ & $\begin{array}{c}0.011 \\
(0.017)\end{array}$ & $\begin{array}{c}0.037^{* * * *} \\
(0.020)\end{array}$ & $\begin{array}{l}0.060 * * \\
(0.027)\end{array}$ \\
\hline Wid & $\begin{array}{l}-0.007 \\
(0.051)\end{array}$ & $\begin{array}{c}0.022 \\
(0.085)\end{array}$ & $\begin{array}{c}-0.107^{* *} \\
(0.05)\end{array}$ & $\begin{array}{l}-0.06 \\
(0.04)\end{array}$ & $\begin{array}{l}0.0006 \\
(0.047)\end{array}$ & $\begin{array}{c}0.016 \\
(0.063)\end{array}$ \\
\hline $\begin{array}{l}\text { Professions: } \\
\text { Prof }\end{array}$ & $\begin{array}{c}0.035 \\
(0.053)\end{array}$ & $\begin{array}{c}0.108 \\
(0.081)\end{array}$ & $\begin{array}{c}0.013 \\
(0.051)\end{array}$ & $\begin{array}{c}0.04 \\
(0.037)\end{array}$ & $\begin{array}{c}0.014 \\
(0.043)\end{array}$ & $\begin{array}{l}-0.053 \\
(0.058)\end{array}$ \\
\hline Tech & $\begin{array}{l}-0.36^{*} \\
(0.042)\end{array}$ & $\begin{array}{c}- \\
0.118^{* * * *} \\
(0.067)\end{array}$ & $\begin{array}{l}-0.27^{*} \\
(0.04)\end{array}$ & $\begin{array}{l}-0.414^{*} \\
(0.031)\end{array}$ & $\begin{array}{l}-0.545 * \\
(0.035)\end{array}$ & $\begin{array}{c}-0.616^{*} \\
(0.047)\end{array}$ \\
\hline Clerk & $\begin{array}{l}-0.445^{*} \\
(0.045)\end{array}$ & $\begin{array}{l}-0.106 \\
(0.075)\end{array}$ & $\begin{array}{l}-0.33^{*} \\
(0.045)\end{array}$ & $\begin{array}{c}-0.523 * \\
(0.034)\end{array}$ & $\begin{array}{c}-0.644 * \\
(0.038)\end{array}$ & $\begin{array}{c}-0.707^{*} \\
(0.052)\end{array}$ \\
\hline Serv & $\begin{array}{l}-0.596^{*} \\
(0.046)\end{array}$ & $\begin{array}{c}-0.371^{*} \\
(0.079)\end{array}$ & $\begin{array}{c}-0.527^{*} \\
(0.046)\end{array}$ & $\begin{array}{c}-0.659^{*} \\
(0.035)\end{array}$ & $\begin{array}{c}-0.797^{*} \\
(0.039)\end{array}$ & $\begin{array}{l}-0.862^{*} \\
(0.053)\end{array}$ \\
\hline Skil & $\begin{array}{l}-0.670^{*} \\
(0.061)\end{array}$ & $\begin{array}{c}- \\
0.250 * * * \\
(0.130)\end{array}$ & $\begin{array}{c}-0.495^{*} \\
(0.080)\end{array}$ & $\begin{array}{c}-0.752 * \\
(0.059)\end{array}$ & $\begin{array}{l}-0.93^{*} \\
(0.068)\end{array}$ & $\begin{array}{c}-1.059^{*} \\
(0.090)\end{array}$ \\
\hline Craft & $\begin{array}{c}-0.529^{*} \\
(0.046)\end{array}$ & $\begin{array}{c}-0.331^{*} \\
(0.08)\end{array}$ & $\begin{array}{c}-0.485^{*} \\
(0.046)\end{array}$ & $\begin{array}{c}-0.590^{*} \\
(0.034)\end{array}$ & $\begin{array}{c}-0.686^{*} \\
(0.038)\end{array}$ & $\begin{array}{l}-0.719 * \\
(0.052)\end{array}$ \\
\hline Plant & $\begin{array}{c}-0.582^{*} \\
(0.051)\end{array}$ & $\begin{array}{c}-0.269^{*} \\
(0.091)\end{array}$ & $\begin{array}{c}-0.514^{*} \\
(0.054)\end{array}$ & $\begin{array}{c}-0.668^{*} \\
(0.039)\end{array}$ & $\begin{array}{c}-0.815^{*} \\
(0.045)\end{array}$ & $\begin{array}{c}-0.809 * \\
(0.060)\end{array}$ \\
\hline Elem & $\begin{array}{c}-0.623^{*} \\
(0.045)\end{array}$ & $\begin{array}{c}-0.275^{*} \\
(0.08)\end{array}$ & $\begin{array}{l}-0.48 * \\
(0.046)\end{array}$ & $\begin{array}{c}-0.693 * \\
(0.034)\end{array}$ & $\begin{array}{c}-0.900^{*} \\
(0.038)\end{array}$ & $\begin{array}{l}-0.992 * \\
(0.051)\end{array}$ \\
\hline $\begin{array}{l}\mathrm{R}^{2} / \text { Pseudo } \\
\mathrm{R}^{2}\end{array}$ & 0.46 & 0.22 & 0.29 & 0.34 & 0.36 & 0.36 \\
\hline F-statistic & 335.18 & - & - & - & - & - \\
\hline $\mathrm{N}$ & 9,894 & 9,894 & 9,894 & 9,894 & 9,894 & 9,894 \\
\hline
\end{tabular}

Notes: 1) The standard errors are given in parentheses.

2) The standard errors are robust to heteroskedasticity.

$3) *, * *, * * *$ denote statistical significance at the $1 \%, 5 \%$ and $10 \%$ level respectively using two-tailed test.

4) The base categories are omitted from the model to avoid dummy variable trap. 
Table-4: Rates of Return to Educational Qualifications

\begin{tabular}{lccc}
\hline Education & ROR & ROR & Differential \\
& $(2005-06)$ & $(1990-91)$ & \\
\hline Primary & $0.0103^{*}$ & $0.0102^{*}$ & 0.0001 \\
& $(0.0037)$ & $(0.0038)$ & $(0.005)$ \\
Middle & $0.0248^{*}$ & $0.039^{*}$ & -0.0142 \\
& $(0.0079)$ & $(0.0075)$ & $(0.0109)$ \\
Matriculate & $0.046^{*}$ & $0.065^{*}$ & -0.019 \\
& $(0.0121)$ & $(0.011)$ & $(0.0161)$ \\
Intermediate & $0.081^{*}$ & $0.0715^{*}$ & 0.0098 \\
& $(0.0118)$ & $(0.010)$ & $(0.0154)$ \\
Professional & $0.067^{*}$ & $0.088^{*}$ & -0.021 \\
& $(0.0107)$ & $(0.0073)$ & $(0.0129)$ \\
University & $0.053^{*}$ & $0.0499^{*}$ & 0.0031 \\
& $(0.0064)$ & $(0.0064)$ & $(0.0091)$ \\
Postgraduate & $0.278^{*}$ & $0.1202^{*}$ & $0.1578^{* *}$ \\
& $(0.0785)$ & $(0.0187)$ & $(0.0807)$ \\
\hline
\end{tabular}

Notes: 1) The standard errors are given in parentheses.

2 ) $*, * *, * * *$ denote statistical significance at the $1 \%, 5 \%$ and $10 \%$ Level, respectively using two-tailed test.

3) In computing the rates of return we assumed Primary $=5$ years; Middle $=3$ years; Matriculation $=2$ years; Intermediate $=2$ years; Professionals $=5$ years; University $=4$ years; Post graduation $=2$ years.

Table-5: Relative Wages for Occupational Categories

\begin{tabular}{lccc}
\hline ISCO & Occupation & $\begin{array}{c}\text { Relative Wage } \\
(\mathbf{2 0 0 5 / 0 6 )}\end{array}$ & $\begin{array}{c}\text { Relative Wage } \\
\mathbf{( 1 9 9 0 / 9 1 )}\end{array}$ \\
\hline 1 & Managers & $48 \%$ & $56 \%$ \\
2 & Professionals & $52 \%$ & $11 \%$ \\
3 & Technicians & $12 \%$ & $20 \%$ \\
4 & Clerks & $3.6 \%$ & $-1.4 \%$ \\
5 & Services & $-11 \%$ & $-20 \%$ \\
6 & Skilled & $-19 \%$ & $-22 \%$ \\
7 & Crafts & $-5 \%$ & $-0.4 \%$ \\
8 & Plants & $-10 \%$ & $4.6 \%$ \\
\hline
\end{tabular}


The human capital theory proposition of wage premiums for higher education is also supported by estimates for overall labor. Education levels determine countries' absorptive capacity, i.e., their capacity to adopt new technologies. Education affects the capacity of workers to deal with change in the wake of globalization that expects individuals to adapt constantly to new situations. The coefficients for all educational qualifications are statistically positively significant and suggest a sizeable premium to educated employees successively as compared to employees with no formal education in both years. The wage premium has also increased successively for every higher qualification. A postgraduate degree yields the highest earnings $(88 \%$ in $1990 / 91$ and $115 \%$ in $2005 / 06$ ) as compared with no formal education in both years, which also depicts increased wage premiums to postgraduates in the period of trade liberalization. Professional degree holders get higher wages than simple Master's degree holders.

A point worth noting is that earnings are larger in magnitude in 1990/91 than in 2005/06 for each qualification in comparison with the base category except postgraduates. The question arises whether the quality of education up to university level in the period of trade liberalization does not meet the demands of globalization and has not increased workers' productivity to accord them better returns and better jobs. Another reason for the lower earnings at each level of education other than postgraduate in 2005/06 could be the nonabsorption of overall labor in job markets in Pakistan. This points to 'under-employment' in the job market. Educated workers who earned less in 2005/06 than 1990/91 may be an indicator of the inability of workers to get jobs and wages according to their potential, thus forcing them to work at a lower wage level. This also points out labor demand constraints in the labor market. Comparatively, the supply of postgraduate employees is considerably less than demand in the labor market and the wage premium for postgraduate degree-holders has increased in the phase of trade liberalization.

However, the computed return to educational qualifications shows no statistically significant differences across time other than postgraduate as reported in Table 4 . Table 4 reports the rate of return to education in both years with their differentials, reported in column (3) and provides evidence of how returns have evolved over the period of trade liberalization. The difference in returns appears statistically significant at the 5\% level of significance for postgraduates only and shows a $15 \%$ increase in returns to postgraduate degrees in the period of trade liberalization. For all other educational categories this appears insignificant, either negative or positive, and hence suggests no meaningful difference. It is important to point out that the same trend in the rate of return to education for overall labor was 
found by Psacharopoulos (2002). In his study, the rate of return to primary level of education was $8.4 \%$, for secondary level, $13.7 \%$, and $31.2 \%$ for higher education in 1991. In Pakistan, the overall rate of return to education is computed at $15.4 \%$ for the same year.

At each quantile, educated workers earn more than workers with no formal education, which suggests a sizeable wage gap among workers with different qualifications. Postgraduate degree holders earn higher wages in each quantile in 2005/06 than 1990/91 while wages are lower for all other qualifications in 2005/06 than 1990/91. Overall returns to education indicate the significant role of education, but in the period of trade liberalization only a postgraduate degree is capable of providing wage premiums to workers.

\section{Gender Wage Gap and Marital Status}

Estimates for the variable gender yield a positive and statistically significant value indicating that males earn significantly more than females. The estimate shows that males earned about $15 \%$ more than females in 1990/91; the gender pay gap has widened over time and males earned almost $25 \%$ more in 2005/06. With regard to the quantile regression estimates, there is little evidence of an increased gender wage-gap moving across the conditional wage distribution in a year. At the lowest paid jobs males are getting significantly more than females but the wage gap contracts when we move along the wage distribution and the difference in wages for the highest paid jobs disappears in 2005/06. The wage gap between lowpaid jobs in 2005/06 is more pronounced than in 1990/91. This implies that trade liberalization has influenced the wage gap in favor of males over time but that, in the highest paid jobs, this effect was not as acute.

Hence, the evidence from the labor market of Pakistan suggests that the ceteris paribus gender pay gap declined across the wage distribution in the period of trade liberalization. These findings can suggest that "sticky floors' rather than 'glass ceilings' is a possible description of the female experience in Pakistan where women are concentrated in low paying jobs at the bottom end of the wage distribution, while at the top there is little evidence of a ceiling preventing them from gaining parity with men as put forward by Hyder (2005). But a careful observation of the small number of females working at the top-end of wage distribution in the labor market of Pakistan provides a better explanation for such results. This postulates that women are facing considerable obstacles to move upward and to join the highly paid group and hence, there are very few women in high paid jobs while too many women are in low paid jobs, leading to insignificant results 
for wages at the top end. The major hindrances in the way of women moving upward are the gender discrimination on account of cultural restrictions, household responsibilities, and low levels of education and skills.

Regarding marital status, married workers appear to earn more than unmarried workers as the estimate is positively statistically significant. For widowed/divorced workers, the result is insignificant, which could be due to the small number of observations. The result shows that married workers earn $7 \%$ and $4 \%$ more in $1990 / 91$ and $2005 / 06$, respectively. These results are consistent with the belief that married workers earn more because they are more productive than single workers due to their responsibilities of supporting families but in 2005/06 this difference had declined. ${ }^{8}$

\section{Job Attributes}

Job location, another important factor, yields an insignificant coefficient for the year 2005/06, while it is statistically positively significant for $1990 / 91$. Workers belonging to urban areas earned $11 \%$ more than workers in rural areas in 1990/91. However, the location-specific wage gap disappears over time and becomes insignificant by 2005/06.

Similarly, the variable job nature appeared to be negatively statistically significant for casual and piece rate workers in both years as compared with regular pay employees. The estimates postulate that casual workers earned almost $30 \%$ less than regular employees in 2005/06 and 26\% less than regular employees in 1990/91 and piece rate workers $37 \%$ and $39 \%$ less than regular employees in 2005/06 and 1990/91, respectively.

Regarding quantile regression results, the estimated coefficients for job nature show that the wage gap has declined among regular and casual and piece rate workers when we move from the lowest to highest wage earners. At the bottom end, the difference between the wages of casual and piece rate workers from regular employees is acute while at the top end this difference is smaller in magnitude. This could imply that, due to globalization, new multinational firms are providing highly paid jobs to workers and we do not find large differences among types of jobs. The lowest paid jobs that are usually locally based have generated wage gaps among workers. However, when observed over time, the wage gap has widened moving from the lowest to highest paid jobs. This indicates

\footnotetext{
${ }^{8}$ Not all variables are required to be analyzed from trade liberalization's point of view as these are included in regression for being a part of traditional earnings function.
} 
increased wage inequality among workers during the period of trade liberalization.

\section{Occupational Categories}

The mean regression estimates yield negatively statistically significant coefficients for all occupational categories other than professionals in 200506, as compared with the base category i.e., managers (legislators, senior officials, and managers) for both years. In 1990/91, the skilled group (market-oriented skilled agricultural and fishery workers) and services group earned about $100 \%$ less than managers, followed by clerks and craft workers who earn $77 \%$ less wages than managers. Similarly, in 2005/06 the lowest wages went to skilled workers, i.e., $95 \%$ less than managers, while elementary workers received $86 \%$ less, services $81 \%$ less, and plant workers $79 \%$ less than managers. In addition, less dispersion is observed in the wages of the eight occupational groups as compared to the managers' group in a given year and the wage gap has contracted for the clerical group, services and skilled workers, widened for elementary workers and more or less remained the same for other groups over the period of trade liberalization.

The relative wage shares to look into the distribution of wages across the occupational groups are obtained by finding the deviation from the weighted average of all occupations and are reported in Table 5. The computed relative wages imply that, on average, skilled, elementary, services, plant and craft workers earn 19\%, 14\%, 11\%, 10\% and 5\% below the average, respectively, while professionals, managers, technicians and clerks earn 52\%, 48\%, $12 \%$ and 3.6\%, above the average in 2005/06. The lowest wage share is that of skilled workers (-19\%) in 2005/06 and the highest wage share is that of professionals $(52 \%)$.

Likewise, the wage share in $1990 / 91$ is $22 \%$ and $20 \%$ below average for the skilled and services group, respectively, whereas managers, technicians, and professionals workers earn 56\%, 20\% and $11 \%$ above the average. The key point is that the lowest wage share goes to the skilled workers' occupational group in both years. Wage dispersion across occupational groups was more pronounced in 1990/91 among the below average wage groups and not very sharp in 2005/06 in any group, which implies a declining trend in wage gaps across occupations. Another remarkable point is that the relative wage share of professionals has increased considerably from $11 \%$ to $52 \%$. The drastic increase in the wage share of professionals shows the enhanced value of this occupation in the new era. The quantile regression estimates yield statistically negatively significant results for all groups other than professionals in 2005/06 and 
suggest lower returns to each profession as compared with managers for both years. This difference is more acute at the top-end of the wage distribution in 2005/06 whereas in 1990/91 it is severe for most occupations at the bottom-end. This postulates that in the period of trade liberalization, workers associated with highly paid jobs are earning higher returns than managers. The wage gap has widened not only moving along the wage distribution toward the upper quantile of wage distribution but this gap has also widened at the top-end of wages over the period of trade liberalization. The wages in highly-paid jobs (managers and professionals in both years) are highly responsive to trade liberalization.

Overall, mean regression estimates display the expanding trend in the wage gaps in the period of trade liberalization in the labor market of Pakistan with some exceptions. More specifically, the gender gap has widened over time and the rate of return to the highest educational degree, i.e., postgraduate, has statistically significantly increased in the trade liberalization period - an indication of rising wage inequality among workers with highest educational qualification. The relative wages of different occupational groups have changed by a significant margin in highly paid jobs specifically while professionals' wage share has increased by great margin.

\section{Conclusions and Policy Suggestions}

This study was intended to estimate the supply-side determinants of wages in the labor market that are specific to each worker. Subsequently, these factors were compared across two time periods, 2005-06 and 1990-91 from various perspectives: gender gap, human capital theory, job attributes and others to examine the effects of trade liberalization. The rate of return to educational qualifications and relative wage shares to nine occupations were also computed in order to gain a deeper insight. Overall, the results obtained suggest an increasing gender pay gap, some degree of stability in the rate of return to most educational qualifications but increased returns to the highest qualification in the period of trade liberalization, and relative wage shares have changed slightly across occupations. In addition, the pattern of wage premiums vary with human capital factors, gender and occupations along the conditional wage distribution.

In the light of these results, our major findings by no means imply that opening up trade should be avoided but the labor market needs to be adjusted to reap the benefits of trade liberalization. One striking point in pursuance of the effect of insufficient trade reforms on wage structure is that (i) either trade reforms have been implemented in such way that they are not capable of affecting the labor market, or (ii) labor market rigidities 
do not allow these effects. Different implications flow from these results. The educational rates of return provide incentives for investing in education as the average wage to all educational categories is almost successively higher than that of workers with no formal education and the rate of return also tends to increase from lower to higher with the degree of education over time. However, education must be in accordance with the new demands of technically-induced trade liberalization. On the one hand, the findings recommend that the Government generate sufficient jobs in accordance with educational qualifications and improve job market conditions while on the other, it urges the workers to attain an education level that is in keeping with competition in the new era.

Although trade liberalization cannot be considered a binding force as far as workers' decisions to acquire education are concerned, it can motivate them to adapt to prevailing market conditions. From the occupational choices view point, although this does not demand that workers switch from their existing profession to the highest paid job available, it is important that they keep up to mark in the new era of trade liberalization, to be able to compete with the new skill-demanding and external-oriented environment. The findings suggested by the study provides some potentially fruitful areas for future research. Control over the quality of education is also worth investigating further. 


\section{References}

Ahmed, V., and R. Amjad, 1984, The Management of Pakistan's Economy, 1947-1982, Oxford University Press, Karachi.

Arbache, J. S., A. Dickerson and F. Green, 2004, "Trade Liberalization and Wages in Developing Countries," The Economic Journal, 114 (493) : F73-F96.

Becker, G., 1962, "Investment in Human Capital: A Theoretical Analysis," Journal of Political Economy, Supplement, Vo1. 70 : 9-49.

Beyer, H. P. Rojas and R. Vergara, 1999, "Trade Liberalization and Wage Inequality,” Journal of Development Economics, Vol. 59 : 103-123.

Dutta, P. V., 2007, "Trade Protection and Industry Wages in India," Industrial and Labor Relations Review, Vol. 60 (2) : 268-286.

Edwards, S., 1993, "Openness, Trade Liberalization, and Growth in Developing Countries," Journal of Economic Literature, Vo1. 31 (3) : 1358-1393.

Feliciano, Z., 2001, "Workers and Trade Liberalization: The Impact of Trade Reforms in Mexico on Wages and Employment," Industrial and Labor Relations Review, Vo1. 55 : 95-115.

Gaston, N. and D. Trefler, 1994, "Protection, Trade and Wages: Evidence from US Manufacturing," Industrial and Labor Relations Review, Vol. 47 (4) : 574-593.

Gindling, T. H., 1991, "Labor Market Segmentation and Determination of Wages in the Public, Private- Formal and Informal Sector in San Jose, Costa Rica.” Economic Development and Cultural Change, Vol. 39 : 585-605.

Goldar, B., 2003, "Trade Liberalization and Real Wages in Organized Manufacturing Industries in India.” Mimeo, Institute of Economic Growth, New Delhi.

Goldar, B., 2002, “Trade Liberalization and Manufacturing Employment: The Case of India,” ILO Employment Paper 34. 
Goldberg, P. K., and N. Pavcnik, 2004, “Trade, Inequality, and Poverty: What Do We Know? Evidence from Recent Trade Liberalization Episodes in Developing Countries." NBER Working Paper No. 10593.

Government of Pakistan, 2004, Economic Survey, Ministry of Finance, Islamabad.

Government of Pakistan, 1990, 2005, Labor Force Survey, Federal Bureau of Statistics (FBS), Islamabad.

Government of Pakistan, 2002, Labor Policy, Ministry of Labor, Manpower and Overseas Pakistanis, Pak. Secretariat, Islamabad.

Green, F., Dickerson, A. and Arbache, J. S., 2001, "A Picture of Wage Inequality and the Allocation of Labor through a Period of Trade Liberalization: The Case of Brazil," World Development, Vol. 29 : 1923-39.

Greenaway, D., R.C. Hine and P. Wright, 1999, "An Empirical Assessment of the Impact of Trade on Employment in the United Kingdom," European Journal of Political Economy, Vo1. 15 : 485-500.

Gyourko, J. and J. Tracy, 1988, "An Analysis of Public and Private-Sector Wages Allowing for both Endogenous Choice of Government and Unions," Journal of Labor Economics, Vol. 6 : 229-253.

Hanson, G. H. and Harrison, A., 1999, “Trade Liberalization and Wage Inequality in Mexico," Industrial and Labor Relations Review, Vo1. $52: 271-88$.

Hasan, R., and L. Chen, 2004, "Trade and Workers: Evidence from the Philippines," Asian Development Review, Vol. 21 (2) : 28-56.

Haque, N, 1984, "Work Status Choice and the Distribution of Family Earnings," Paper 7037, RAND Economic Paper Series.

Heckman, J., 1979, "Sample Selection Bias as a Specification Error," Econometrica, Vo1. 49 : 153-161.

Heckman, J., 1990, "Varieties of Selection Bias," American Economic Review, Vol. 80 : 1121-1149. 
Hyder, A and B. Reilly, 2005, "The Public and Private Sector Pay Gap in Pakistan: A Quantile Regression Analysis," The Pakistan Development Review, 44 (3) : 271-306.

Jean, S., and G. Nicoletti, 2002, "Product Market Regulation and Wage Premia in Europe and North America: An Empirical Investigation," OECD Economics Department Working Paper No. 318.

Kema1, A. R., 1998, "Industrial Development in Pakistan," Pakistan Journal of Applied Economics, Vol. 14 (1 \& 2) : 107-119.

Khan, A. H., 1998, "The Experience of Trade Liberalization in Pakistan," Pakistan Development Review, Vo1. 37 (4) : 661-685.

Khan, S. R. and Irfan, M., 1985, "Rate of Returns to Education and Determinants of Earnings in Pakistan." The Pakistan Development Review, 34 : 3-4.

Krueger, A. O., 1983, Trade and Employment in Developing Countries, Chicago: Chicago University Press.

Krueger, A. O., 1990, "The Relationship between Trade, Employment, and Development," in (G. Ranis and T. Schultz, eds.), The State of Development Economics: Progress and Perspectives, Cambridge: Basil Blackwell.

Krueger, A. B., and Summers, L. H., 1988, "Efficiency Wages and the InterIndustry Wage Structure," Econometrica, Vol. 56 (2) : 259-293.

Koenker, R., 2005, Quantile Regression, Econometric Society Monographs \# 38, Cambridge University Press.

Koenker, R. and G. Bassett, 1978, "Regression Quantiles,” Econometrica, Vo1. $46: 33-50$.

Koenker, R., and K. Hallock, 2001, "Quantile Regression," Journal of Economic Perspectives, Vol. 15 (4) : 143-156.

Krueger, A.B., 1988, "The Determinants of Queues for Federal Jobs," Industrial and Labor Relations Review, Vo1. 41 : 567-581.

Keeley, M., 1977, “The Economics of Family Formation," Economic Inquiry, Vo1. $15: 238-250$. 
Kenny, L., 1983, "The Accumulation of Human Capital during Marriage by Males,” Economic Inquiry, Vol. 21 : 223-231.

Lau, L., D. Jamison and F. Louat, 1990, "Education and Productivity in Developing Countries: An Aggregate Production Function Approach," The World Bank, Washington, DC, Mimeo.

Lee, L., 1978, "Unionism and Wage Rates: A Simultaneous Equation Mode1 with Qualitative and Limited Dependent Variables," International Economic Review, Vo1. 19 : 415- 433.

Lee, L., 1983, “Generalized Models with Selectivity,” Econometrica, Vo1. 51 : 507-512.

Mincer, J., 1962, "On-the-job Training: Costs, Returns, and Some Implications," The Journal of Political Economy, Vol. 70 : 550-579.

Mincer, J., 1974, Schooling, Experience, and Earnings, New York: NBER and Columbia University Press.

Mincer, J. and H. Ofek, 1982, "Interrupted Work Careers: Depreciation and Restoration of Human Capital," The Journal of Human Resource, Vol. $15: 3-24$.

Mosteller, F., and John Tukey, 1977, Data Analysis and Regression: A Second Course in Statistics, Reading, Mass: Addison-Wesley.

Nakosteen, R., and M. Zimmer, 1982, "Marital Status and Earnings of Young Men,” Journal of Human Resources, Vo1. 22 : 248-268.

Psacharopoulos, G., 1994, "Return to Investment in Education: A Global Update," World Development, Vo1. 22 : 1325-1325.

Robbins D., 1996, "HOS Hits Facts: Facts Win; Evidence on Trade and Wages in the Developing World," Development Discussion Paper No. 557, Harvard Institute for International Development, Harvard University.

Robbins, D. J., and Gindling, T. H., 1999, "Trade Liberalization and the Relative Wages for More-Skilled Workers in Costa Rica," Review of Development Economics, Vo1. 3 : 140-54.

Rodrik, D., 1997, Has Globalization Gone too Far? Institute for International Economics, Washington DC. 
Sayeed, A., 1995, "Political Alignments, the State and Industrial Policy in Pakistan: A Comparison of Performance in the 1960s and 1980s," unpublished $\mathrm{PhD}$ dissertation, University of Cambridge.

Shabbir, T, 1994, "Mincerian Earning Functions for Pakistan," The Pakistan Development Review, Vol. 33 (1).

Shultz, T. W., 1961, "Investment in Human Capital," The American Economic Review, Vol. 2 : 1-17.

Terre11, K., 1993, "Public-Private Wage Differentials in Haiti: Do Public Servants Earn a Rent?” The Journal of Development Economic, Vol. $42: 293-314$.

Wood, A., 1994, North-South Trade, Employment and Inequality. Changing Fortunes in Skill-Driven World, Oxford: Clarendon Press.

Wood, A., 1997, “Openness and Wage Inequality in Developing Countries: The Latin American Challenge to East Asian Conventional Wisdom," The World Bank Economic Review, Vo1. 11 (1) : 33-58.

Wood, A., 1999, "Openness and Wage Inequality in Developing Countries: The Latin American Challenge to East Asian Conventional Wisdom," in (R. E. Baldwin, D. Cohen, A. Sapir and A. Venables, eds.), Market Integration, Regionalism and Global the Economy, Cambridge: Cambridge University.

Zaidi, S. Akbar, 2004, Issues in Pakistan's Economy, Oxford University Press, Karachi.

Zanchi, L., 1998, "Inter-Industry Wage Differentials in Dummy Variable Models," Economics Letters, Vo1. 60 : 297-301. 